\title{
MicroRNAs 142-3p, miR-155 and miR-203 Are Deregulated in Gastric MALT Lymphomas Compared to Chronic Gastritis
}

\author{
CONCEPCIÓN FERNÁNDEZ ${ }^{1,2,3}$, BEATRIZ BELLOSILLO ${ }^{1,2,4 *}$, MARIANA FERRARO ${ }^{3,5}$, \\ AGUSTÍN SEOANE ${ }^{6}$, BLANCA SÁNCHEZ-GONZÁLEZ ${ }^{2,5}$, SILVIA PAIRET ${ }^{1,2}$, AINA PONS ${ }^{2}$, \\ LUIS BARRANCO ${ }^{6}$, MARÍA CARMEN VELA ${ }^{1}$, EVA GIMENO $^{2,5}$, LLUÍS COLOMO ${ }^{1}$, \\ CARLES BESSES ${ }^{2,5}$, ALFONS NAVARRO $^{7 *}$ and ANTONIO SALAR ${ }^{2,3,5, *}$ \\ ${ }^{1}$ Pathology Department, Hospital del Mar, Barcelona, Spain; \\ ${ }^{2}$ IMIM (Hospital del Mar Medical Research Institute), Barcelona, Spain; \\ ${ }^{3}$ Universitat Autònoma de Barcelona, Barcelona, Spain; \\ ${ }^{4}$ Universitat Pompeu Fabra, Barcelona, Spain; \\ ${ }^{5}$ Hematology Department, Hospital del Mar, Barcelona, Spain; \\ ${ }^{6}$ Digestive Department, Hospital del Mar, Barcelona, Spain; \\ ${ }^{7}$ Molecular Oncology and Embryology Laboratory, Human Anatomy Unit, \\ School of Medicine, University of Barcelona, IDIBAPS, Barcelona, Spain
}

\begin{abstract}
Background: Over the last years, our knowledge on pathogenesis of gastric MALT lymphoma has greatly improved, but its morphological diagnosis is still hampered by overlapping histological features with advanced chronic gastritis. MicroRNAs are deregulated in lymphomas, but their role and usefulness in gastric MALT lymphoma has not been extensively investigated. Materials and Methods: We analyzed the expression of 384 miRNAs using TaqMan microRNA assay in a training series of 10 gastric MALT lymphomas, 3 chronic gastritis and 2 reactive lymph nodes. Then, significantly deregulated miRNAs were individually assessed by real-time PCR in a validation series of 16 gastric MALT lymphomas and 12 chronic gastritis. Results: Gastric MALT lymphoma is characterized by a specific miRNA expression profile. Among the differentially expressed miRNAs, a significant overexpression of miR-142-3p and miR-155 and down-regulation of miR-203 was observed in gastric MALT lymphoma when compared to chronic gastritis. Conclusion: miR-142-3p, miR-155 and miR-203 expression levels might be helpful biomarkers for the differential diagnosis between gastric MALT lymphomas and chronic gastritis.
\end{abstract}

This article is freely accessible online.

*These Authors contributed equally to this study.

Correspondence to: Beatriz Bellosillo, Department of Pathology, Hospital del Mar-IMIM, Passeig Maritim 25-29, 08003, Barcelona, Spain. Tel: 003493 2483561, e-mail: bbellosillo@parcdesalutmar.cat

Key Words: MicroRNAs, miR-155, miR-203, gastric MALT lymphoma, chronic gastritis.
Extranodal marginal-zone B-cell lymphoma of mucosaassociated lymphoid tissue (MALT) is a rare form of indolent non-Hodgkin's lymphoma. These tumors can arise at any extranodal site and the stomach is the most common location, accounting for almost half of all MALT lymphoma cases $(1,2)$. Chronic antigen-dependent immune stimulation by Helicobacter pylori infection is under the pathogenesis of gastric MALT lymphomas $(3,4)$, although the mechanisms underlying the transformation from chronic gastritis to gastric MALT lymphoma are insufficiently characterized. Several chromosomal abnormalities have been described in gastric MALT lymphoma, with translocation $\mathrm{t}(11 ; 18)(\mathrm{q} 21 ; \mathrm{q} 21)$ being the most frequent (5). Histopathological diagnosis of gastric MALT lymphoma is often difficult due to the overlapping histological features observed in chronic gastritis during progressive transformation to overt gastric MALT lymphoma (6). The scorebased classification system, as proposed by Wotherspoon and colleagues, supplemented by molecular clonality assessment of the B-cell population has certainly improved the diagnostic accuracy (7). However, the correct diagnosis of some cases remains challenging in the daily practice.

MicroRNAs are small non-coding RNAs that modulate gene expression on a post-transcriptional level. MicroRNAs can function as endogenous silencers of target genes and play critical roles in cellular proliferation, apoptosis and differentiation $(8,9)$. MicroRNAs have been described to have important roles as tumor suppressor genes and oncogenes in human malignancies, including lymphomas $(10,11)$.

Several oncogenic pathways are involved in gastric MALT lymphomagenesis $(1,6,12)$. Interestingly, the number of genes that are differentially expressed between chronic 
gastritis versus MALT lymphoma is remarkably low (13), indicating that these two disorders are biologically related. Recently, several microRNAs have been identified to be involved in the process of neoplastic transformation in nonHodgkin's lymphomas $(10,11,14-17)$. Only a few studies have analyzed the role of microRNAs in gastric MALT lymphomas, as diagnostic or prognostic tools $(18,19)$. This study aimed to identify aberrantly expressed microRNAs that can be helpful in the accurate classification of these entities during the diagnostic process.

\section{Materials and Methods}

Patient samples. Biopsy samples from 32 patients diagnosed with gastric MALT lymphoma according to the World Health Organization (WHO) classification (20) and the criteria of Wotherspoon et al. (21) were reviewed and included in the study. All gastric MALT lymphomas had scores 3-5 and were clonal. $H$. pylori status was determined by histology and/or urea breath test, or serology in negative cases. All patients underwent disease extension study that included medical history, physical examination, laboratory, computed tomography scans, unilateral bone marrow biopsy and upper endoscopy with multiple gastric biopsies. Stage was determined according to Lugano system, as previously reported (22). From the 32 patients, 3 cases were discarded due to insufficient material and 3 cases due to technical reasons. The 26 remaining cases were divided in 2 different groups according to availability of fresh-frozen material. (1) Training series: 10 patients with available frozen material; (2) Validation series: 16 independent patients with available formalin-fixed paraffin-embedded (FFPE) tissue material.

Cryopreserved tissue specimens from 3 chronic gastritis and 2 reactive lymph nodes were used in the training series as control samples. In addition, 12 paraffin-embedded tissue samples diagnosed of chronic gastritis (associated or not to H. pylori infection) were drawn from the MarBiobanc and were used in the validation series. Gastritis was considered in scores 1-2 which were not clonal.

All samples were obtained from the tissue bank of MarBiobanc Hospital del Mar, Barcelona, Spain. The study was approved by the institution's medical ethics committee, and tissue and clinical data were retrieved according to the regulations of the institutional review board (Comitè Ètic d'Investigació Clínica del Parc de Salut Mar CEIC-PSMAR) and data protection laws.

Immunohistochemistry, cytogenetic and clonality studies. A series of immunohistochemical stains were performed in consecutive sections including CD20 (L26)(DAKO), CD3 (F7.2.38) (Novocastra), Bcl-10 (clone 151.1, MBL Medical and Biological Laboratories, Nagoya, Japan) and Ki67(MIB1)(DAKO), as previously reported $(23)$. The $\mathrm{t}(11 ; 18)(\mathrm{q} 21 ; \mathrm{q} 21)$ was analyzed on all diagnostic specimens using fluorescent in situ hybridization (FISH) with the commercially available break-apart LSI-MALT1 probe (Vysis, Downers Grove, IL, USA) or by reverse transcriptase-PCR (RT-PCR) for API2/MALT1 fusion product, as previously described (22). Immunoglobulin gene rearrangements were analyzed according to the BIOMED2 protocol (24) as previously described (22).
RNA extraction. Total RNA was extracted from the fresh-frozen samples using Trizol (Invitrogen, Carlsbad, CA, USA) as per the manufacturer's protocol. Total RNA was extracted from formalinfixed paraffin-embedded samples using RecoverAll Total Nucleic Acid Isolation (Ambion, Life Technologies, Carlsbad, CA, USA) as per the manufacturer's protocol. The concentration was quantified using a NanoDrop 1000 Spectrophotometer.

miRNA expression analysis. The miRNA expression profile was analyzed in 10 samples from gastric MALT lymphoma, 3 chronic gastritis and 2 reactive lymph nodes using TaqMan Human MicroRNA Arrays v2.0 (Life Technologies), as described previously (25). Briefly, reverse transcription (RT) reaction was performed on Veriti 96-well thermal cycler for $2 \mathrm{~min}$ at $16^{\circ} \mathrm{C}, 1$ min at $42^{\circ} \mathrm{C}$ and $1 \mathrm{~s}$ at $50^{\circ} \mathrm{C}$ for 40 cycles, and $5 \mathrm{~min}$ at $85^{\circ} \mathrm{C}$, and then held at $4^{\circ} \mathrm{C}$. The RT reaction contained: $0.8 \mu \mathrm{l}$ of $10 \times \mathrm{RT}$ buffer (Life Technologies), $0.2 \mu \mathrm{l}$ dNTPs (100 mm each), $1.5 \mu \mathrm{l}$ MultiScribe Reverse Transcriptase $(50 \mathrm{U} / \mu \mathrm{l}), 0.10 \mu \mathrm{l}$ RNase Inhibitor $(20 \mathrm{U} / \mu \mathrm{l}), 0.80 \mu \mathrm{l}$ Megaplex RT primers (10X), $0.90 \mu \mathrm{l}$ of $\mathrm{MgCl}_{2}(20 \mathrm{U} / \mu \mathrm{l})$ and $500 \mathrm{ng}$ of total RNA. Real-time PCR reaction was performed on an ABI 7900 HT Sequence Detection System (Life Technologies) and contained $450 \mu$ of TaqMan Universal PCR Master Mix No Amperase (2X) (Life Technologies), $6 \mu$ Megaplex RT product and $444 \mu 1$ nuclease-free water. The relative miRNA expression was calculated using the $2-\Delta \Delta C t$ method. Normalization was performed with RNU6B. All miRNAs expressed in $<10 \%$ of samples were excluded from further analysis, leaving a working set of 234 miRNAs.

Selected miRNAs identified in the profile study were analyzed in 16 independent gastric MALT lymphoma and 12 chronic gastritis using TaqMan microRNA assays. Briefly, cDNA was synthesized from total RNA using gene-specific primers according to the TaqMan MicroRNA Assay protocol. Reverse transcriptase (RT) reactions contained $10 \mathrm{ng}$ of RNA samples, $50 \mathrm{nM}$ stem-loop RT primer, $1 \times$ RT buffer, $0.25 \mathrm{mM}$ each of dNTPs, $3.33 \mathrm{U} / \mu \mathrm{l}$ MultiScribe reverse transcriptase and $0.25 \mathrm{U} / \mu \mathrm{l}$ RNase Inhibitor. The 7.5- $\mu$ l reactions were incubated in an Applied Biosystems (Foster City, CA, USA) Veriti Thermal Cycler in a 96-well plate for $30 \mathrm{~min}$ at $16^{\circ} \mathrm{C}, 30 \mathrm{~min}$ at $42^{\circ} \mathrm{C}, 5 \mathrm{~min}$ at $85^{\circ} \mathrm{C}$ and then held at $4^{\circ} \mathrm{C}$. Real-time PCR was performed using an Applied Biosystems 7500 Fast System. The 10- $\mu$ l PCR included $0.67 \mu \mathrm{l}$ RT product, $1 \times$ TaqMan Universal PCR master mix and $1 \mu \mathrm{l}$ of primers and probe mix. The reactions were incubated in a 96 -well optical plate at $95^{\circ} \mathrm{C}$ for $10 \mathrm{~min}$, followed by 40 cycles of $95^{\circ} \mathrm{C}$ for $15 \mathrm{~s}$ and $60^{\circ} \mathrm{C}$ for 1 min. RNU6B was used as endogen control. All assays were performed in triplicate.

Statistical analysis. MicroRNA profiling data were analyzed using TIGR Multiexperiment viewer version 4.0 software (DanaFarber Cancer Institute, Boston, MA, USA). Hierarchical clustering was performed using Euclidean distance and complete linkage. To identify miRNAs with significant differential expression between subgroups Student's $t$-test based on multivariate permutation (with random variance model) was used. Differences between miRNAs were considered statistically significant if corrected $p<0.05$. To compare expression values of microRNAs in the validation series between groups $t$-test was performed in GraphPad Prism 6 (GraphPad Software, Inc., San Diego, CA, USA). Differences at $p<0.05$ were considered significant. 


\section{Results}

miRNA expression characterizes gastric MALT lymphoma versus chronic gastritis. We performed miRNA profiling of 10 gastric MALT lymphoma cases, 3 chronic gastritis and 2 reactive lymph nodes by real-time PCR using arrays that allow simultaneous analysis of 384 miRNAs. After filtering and normalization, all miRNAs expressed in $<10 \%$ of samples were excluded from further analysis, leaving a working set of 234 miRNAs.

The unsupervised hierarchical clustering analysis showed that gastric MALT lymphoma is characterized by a specific miRNA profile since all the lymphoma samples clustered together. Moreover, the 3 chronic gastritis samples and the 2 reactive lymph nodes formed 2 additional groups (Figure 1A). The supervised analysis identified 15 deregulated miRNAs, thirteen of them showing decreased expression levels in the gastric MALT lymphoma samples (Figure 1B) when compared to control samples.

We selected four of the fifteen miRNAs for validation in an independent set of samples. The miRNAs analyzed were the two overexpressed miRNAs, miR-142-3p and miR-155, and the two most significantly down-regulated miRNAs miR-203 and miR378. We then performed individual miRNA expression assays with the 16 gastric MALT lymphomas (baseline characteristics summarized in Table I) and 12 chronic gastritis. These expression assays confirmed the overexpression of miR-142-3p $(p=0.0001)$ and miR-155 $(p<0.0001)$ and the downregulation of miR-203 ( $p=0.0299)$ in gastric MALT lymphomas compared to chronic gastritis. The differential expression of miR-378 could not be confirmed in the validation series (Figure 1C).

Gastric MALT lymphomas with $t(11 ; 18)(q 21 ; q 21)$ harbors a specific miRNA profile. We next analyzed whether the miRNA expression profile was related to the presence of the $\mathrm{t}(11 ; 18)(\mathrm{q} 21 ; \mathrm{q} 21)$ translocation. Although the limited number of patients with the $\mathrm{t}(11 ; 18)(\mathrm{q} 21 ; \mathrm{q} 21)$ included in the initial cohort $(n=5)$, the supervised analysis identified seventeen differentially expressed miRNAs between patients carrying or not $\mathrm{t}(11 ; 18)(\mathrm{q} 21 ; \mathrm{q} 21)$ (Figure 2A). Interestingly, two of these miRNAs, miR-100 and miR-187, were encoded at chromosomes 11(chr11: 122152229-122152308 [-]) and 18 (chr18: 35904818-35904926 [-]), respectively. We selected miR-100 and miR-187 for validation in the independent set of patients, which included 3 patients with $\mathrm{t}(11 ; 18)(\mathrm{q} 21 ; \mathrm{q} 21)$. We observed an increased expression of both miR-100 and miR187 in cases carrying the translocation, although differences did not reach statistical significance ( $p=0.077$ and $p=0.066$, respectively; Figure $2 \mathrm{~B}$ ), probably due to the limited number of cases available with the $t(11 ; 18)$ translocation $(n=3)$.

Overexpression of miR-155 in multifocal gastric MALT lymphoma. Finally, we evaluated all previously selected
Table I. Patient's characteristics in training and validation series

\begin{tabular}{|c|c|c|}
\hline & $\begin{array}{l}\text { Training series } \\
\qquad \begin{array}{c}(\mathrm{n}=10) \\
\mathrm{N}(\%)\end{array}\end{array}$ & $\begin{array}{l}\text { Validation series } \\
\qquad \begin{array}{c}(\mathrm{n}=16) \\
\mathrm{N}(\%)\end{array}\end{array}$ \\
\hline Age median, years (range) & $63(32-85)$ & $70.5(36-88)$ \\
\hline Gender, male & $7(70 \%)$ & $10(62.5 \%)$ \\
\hline \multicolumn{3}{|l|}{ Lugano stage } \\
\hline I-II & $8(80 \%)$ & $13(81.2 \%)$ \\
\hline III-IV & $2(20 \%)$ & $3(18.8 \%)$ \\
\hline Multifocal & $2(20 \%)$ & $3(18.8 \%)$ \\
\hline H. pylori-positive & $5(50 \%)$ & $10(62.5 \%)$ \\
\hline $\mathrm{t}(11 ; 18)$-positive & $5(50 \%)$ & $3(18.8 \%)$ \\
\hline
\end{tabular}

miRNAs according to dissemination (localized $v s$. multifocal) only in the validation series, since in the training cohort only 2 patients had multifocal stage. At the validation series, 13 out of 16 patients were in Lugano stage I (localized) and 3 were in stage IV (multifocal). Only miR155 was found to be significantly up-regulated in multifocal gastric MALT lymphoma $(p=0.0099)$.

\section{Discussion}

In this study, we examined the expression profile of 384 selected miRNAs in gastric MALT lymphomas and our results showed that these tumors have a miRNA expression profile different from chronic gastritis samples or normal lymphoid tissue. Several miRNAs have been described to be differentially expressed in H. pylori infection (e.g. LET7f, miR-155) (26-29) and in the process of neoplastic transformation from $H$. pylori-related chronic gastritis to overt gastric MALT lymphoma (miR-150, miR-550, miR124a, miR-518b and miR-539) (26, 30, 31).

In the current study, we found an up-regulation of miR-155 and miR-142-3p in gastric MALT lymphoma supporting data of several recently published observations attributing to these miRNAs a role in MALT lymphomagenesis $(26,28,30,31)$. MiR-155, encoded by a non-coding RNA BIC, is one of the most extensively studied miRNAs in B cells, being strongly implicated in lymphocyte development and aberrantly upregulated in several B-cell malignancies including diffuse large B-cell lymphoma (DLBCL), follicular lymphoma, chronic lymphocytic leukemia (CLL) and mantle cell lymphoma (3234). Very recently, Due et al. and Wan et al. conducted two comprehensive reviews elucidating the potential of miR-155 as a biomarker in B-cell malignancies and in gastrointestinal tract diseases, respectively. While elevated expression of miR-155 shows potential as a diagnostic and prognostic biomarker as well as an efficient therapeutic target in DLBCL and CLL (35), there are few recent studies focusing on gastric MALT lymphomas $(35,36)$. 
A

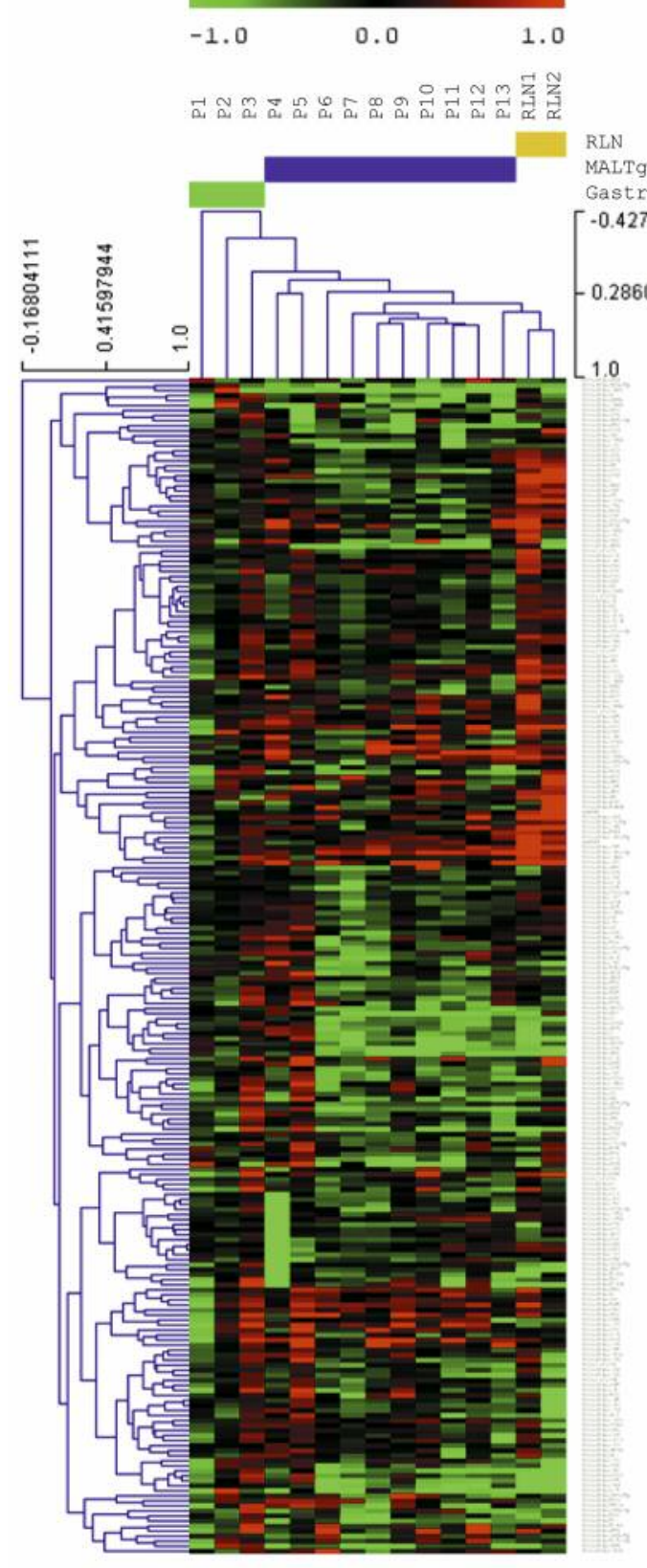

B

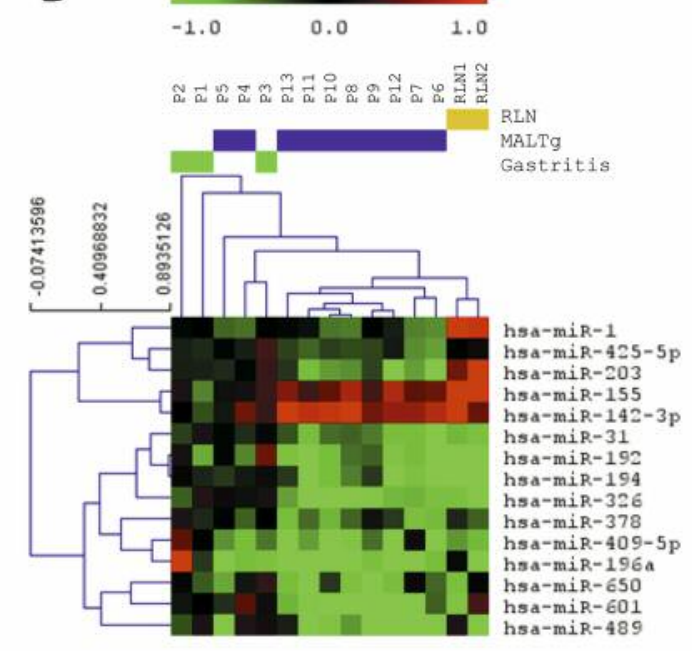

C
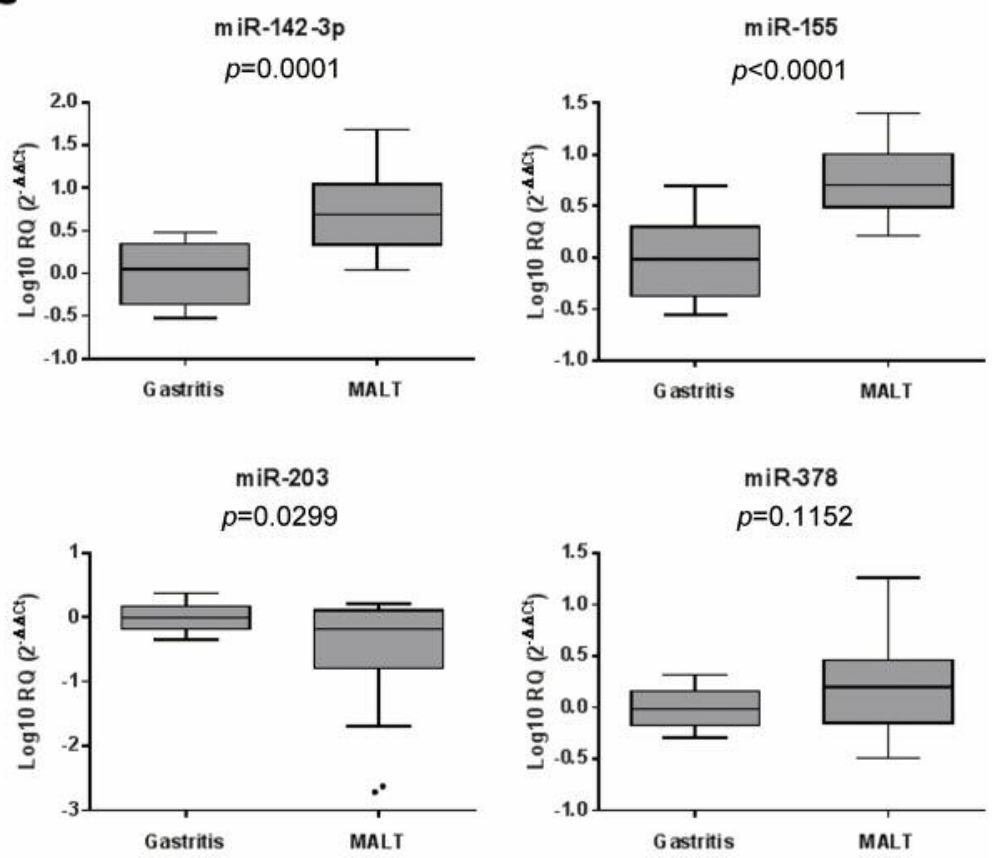

Figure 1. Hierarchical clustering analysis of gastric MALT lymphomas, gastritis and reactive lymph nodes. (A) Unsupervised hierarchical clustering analysis showing the separation of reactive lymph nodes and chronic gastritis from gastric MALT lymphomas. (B) A subset of miRNAs with different expression in gastric MALT lymphoma in comparison to chronic gastritis. (C) Quantitative RT-PCR analysis in the validation cohort of miR-1423p, miR-155, miR-203 and miR-378 in chronic gastritis and gastric MALT lymphomas.

In gastric MALT lymphomas, up-regulation of miR-155 is observed during $H$. pylori infection and may be used as a potential predictor of resistance to $H$. pylori eradication therapy, independently of the predictive value of the API2/MALT1 fusion gene (30). This may be related to the negative inflammatory response against $H$. pylori infection induced by miR-155 (28). In addition, expression of miR155 in B cells is directly activated by NF-kB and MYB, leading to negative down-regulation of the PI3K/AKT pathway through SHIP-1, and this increased miR-155 
A

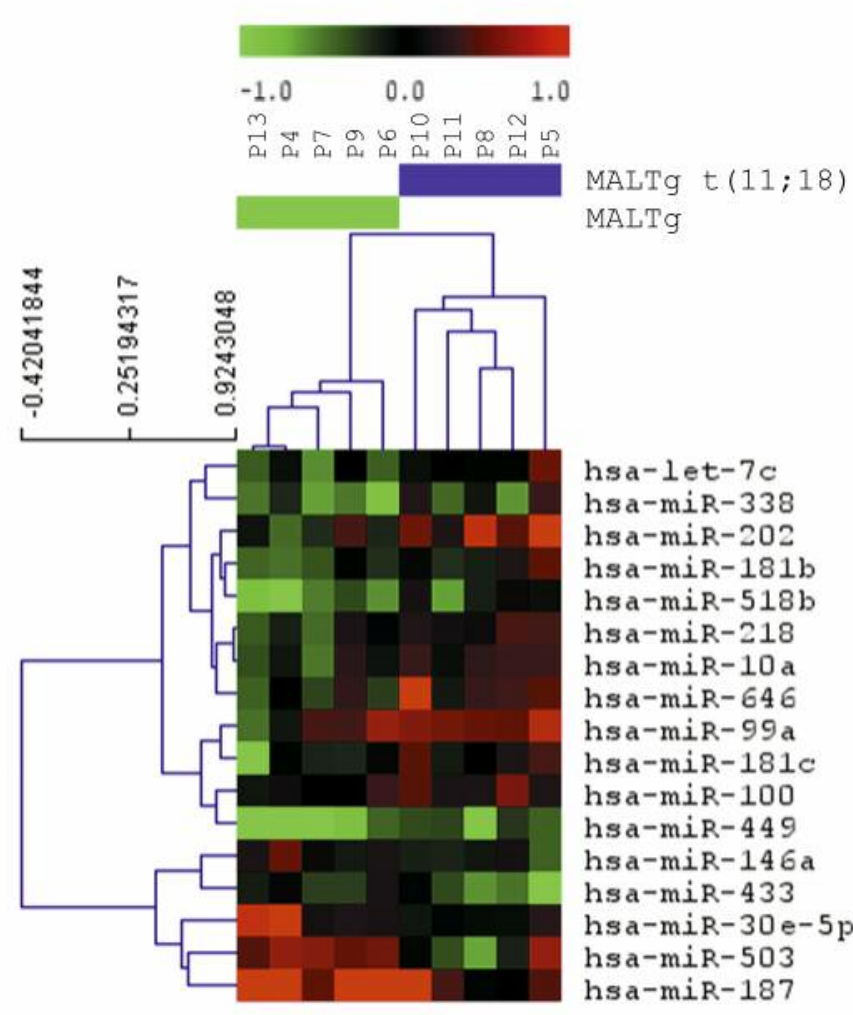

B

$\operatorname{miR}-100$

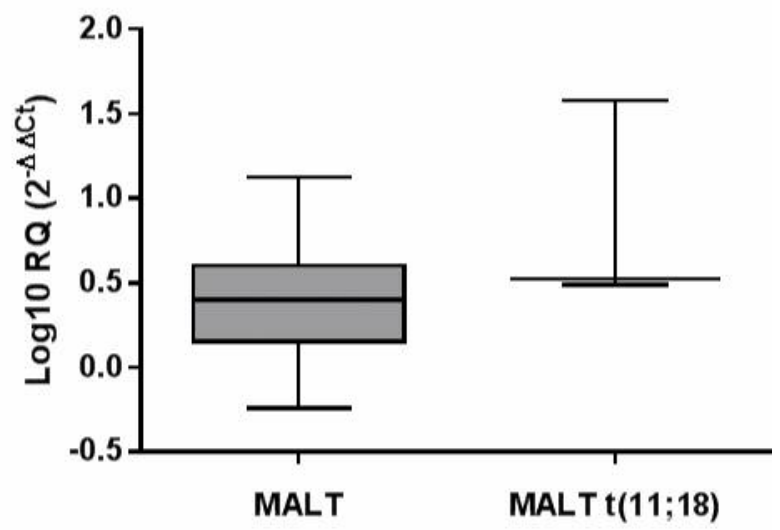

$\operatorname{miR}-187$

$p=0.0665$

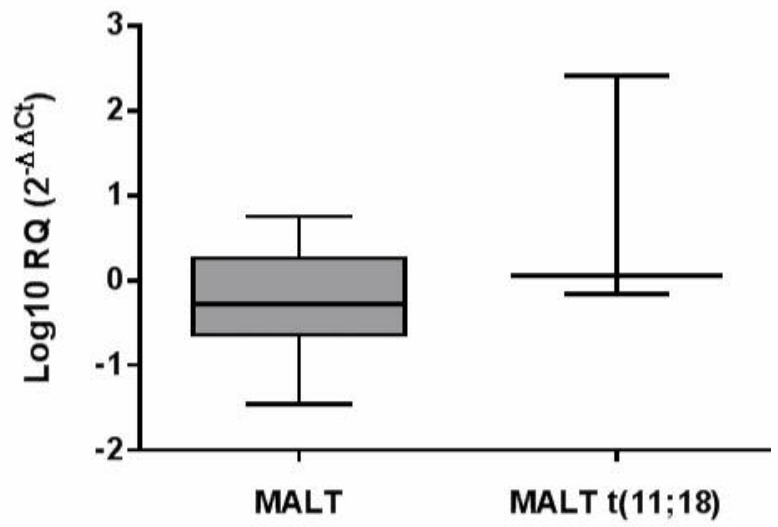

Figure 2. miRNA differentially expressed in gastric MALT lymphomas with $t(11 ; 18)(q 21 ; q 21)$. (A) Supervised hierarchical clustering showing differential expressed miRNAs in the training cohort. (B) Quantitative real time-PCR analysis in the validation cohort of miR-100 and miR-187.

expression in B cells unblocks AKT activity and affects BCR signaling (32). It is well-known that both NF-kB pathway and BCR activation are activated and play a critical role in MALT lymphomagenesis.

Our study also revealed an up-regulation of miR-142-3p in gastric MALT lymphoma compared to chronic gastritis. MiR$142-3 p$ is a member of the miR-142 family, and was first discovered to be involved in an aggressive B-cell leukemia being highly specific for hematopoietic cells (37-39). Our finding of higher miR-142-3p expression in gastric MALT cells, a mature B-cell neoplasia, is in line with published expression data showing a higher expression in mature cells compared to immature hematopoietic cells (39) and also in gastric MALT lymphomas $(30,31)$. Indeed, Saito has suggested that both miR-142 and miR-155 suppress the proapoptotic gene TP53INP1, possibly leading to inhibition of apoptosis and acceleration of MALT lymphoma cell proliferation. Interestingly, inhibition of miRNAs with chemically-engineered oligonucleotides, termed "antagomirs", can work as specific inhibitors of endogenous miRNAs in mice, and might be potentially applicable to silence miR-142 and miR-155 for the treatment of gastric MALT lymphomas that are resistant to $H$. pylori eradication therapy (40-42).

Our results also showed that miR-203 was down-regulated in gastric MALT lymphoma, like other recent published data (26, 43). Craig et al. have described that the progression from $H$. pylori-associated gastritis to low-grade MALT lymphoma is epigenetically regulated by methylation of the 
miR-203 promoter region. Transcriptional repression of miR203 results in dysregulation of ABL1, which in turn drives MALT lymphoma proliferation. Then, expression of miR203 is induced in the course of B-cell maturation, and is secondarily lost as marginal zone B-cells undergo neoplastic transformation during MALT lymphomagenesis (43).

Histopathological diagnosis of gastric MALT lymphoma in the context of morphological overlap between reactive or inflammatory changes during progressive malignant transformation is difficult. The score-based classification system as proposed by Wotherspoon and the use of standardized PCR protocols like the BIOMED2 protocol has certainly improved the diagnostic accuracy. According to our results, discrimination between chronic gastritis and gastric MALT lymphomas on the basis of miRNA expression profiles is feasible. Moreover, we propose that quantitative expression of miR-142-3p and miR-155 may be an additional tool that can help in the challenging process of histologic diagnosis to better differentiate between chronic gastritis and overt gastric MALT lymphoma.

Apart from regulation mechanisms of miRNA expression, cytogenetic aberrations might play a role in miRNA deregulations. In this study, we examined the expression profile of miRNAs according to the presence or absence of $\mathrm{t}(11 ; 18)(\mathrm{q} 21 ; \mathrm{q} 21)$, because patients carrying this translocation have a poor response to antibiotic eradication therapy and to alkylating agents like chlorambucil or cyclophosphamide $(44,45)$. We found 17 miRNAs differentially expressed in the array series and, subsequently, we investigated a series of miRNAs that included some miRNAs mapped to chromosomal regions altered in patients carrying API2-MALT1 translocation. Overexpression of miR100 (chromosome 11) and miR-187 (chromosome 18) was found in cases with $\mathrm{t}(11 ; 18)(\mathrm{q} 21 ; \mathrm{q} 21)$ but not of miR-155, as previously reported by Saito, although the number of patients carrying $\mathrm{t}(11 ; 18)(\mathrm{q} 21 ; \mathrm{q} 21)$ in both studies is limited.

Finally, we also investigated the contribution of miRNA expression in the dissemination trend of gastric MALT lymphomas. We found 23 miRNAs to be differentially expressed according to the dissemination presentation of the disease, with miR-142-3p, miR-155 and miR-222 being the most significantly down-regulated miRNAs. Gastric MALT lymphomas with higher expression of miR-223, a memory B-cell-associated miRNA, have been described to have a tendency to involve perigastric lymph nodes (18). Unfortunately, we did not have stage II cases in the validation series to corroborate this observation.

In summary, gastric MALT lymphomas have differentially expressed miRNAs when compared to chronic gastritis. We validated the overexpression of miR-155 and miR-124-3p and down-regulation of miR-203, which could be used as novel biomarkers for improving the often difficult process of gastric MALT lymphomas diagnosis.

\section{Conflicts of Interest}

The Authors declare no conflict of interest.

\section{Acknowledgements}

This work was supported by Grants from Instituto de Salud Carlos III FEDER (FIS 07/0586, FIS 15/0459, PT13/0010/0005), 2014 SGR 567, and the "Xarxa de Bancs de tumors" sponsored by Pla Director d'Oncologia de Catalunya (XBTC). Concepción Fernández-Rodríguez received a fellowship from the Ministry of Economy and Competitiveness of Spain (PFIS grant FI11/00353).

\section{References}

1 Isaacson $\mathrm{P}$ and Wright DH: Malignant lymphoma of mucosaassociated lymphoid tissue. A distinctive type of B-cell lymphoma. Cancer 52: 1410-1416, 1983.

2 Thieblemont C, Bastion Y, Berger F, Rieux C, Salles G, Dumontet C, Felman P and Coiffier B: Mucosa-associated lymphoid tissue gastrointestinal and nongastrointestinal lymphoma behavior: analysis of 108 patients. J Clin Oncol 15: 1624-1630, 1997.

3 Parsonnet J, Hansen S, Rodriguez L, Gelb AB, Warnke RA, Jellum E, Orentreich N, Vogelman JH and Friedman GD: Helicobacter pylori infection and gastric lymphoma. N Engl J Med 330: 12671271, 1994.

4 Starostik P, Patzner J, Greiner A, Schwarz S, Kalla J, Ott G and Müller-Hermelink HK: Gastric marginal zone B-cell lymphomas of MALT type develop along 2 distinct pathogenetic pathways. Blood 99: 3-9, 2002.

5 Yeh KH, Kuo SH, Chen LT, Mao TL, Doong SL, Wu MS, Hsu HC, Tzeng YS, Chen CL, Lin JT and Cheng AL: Nuclear expression of BCL10 or nuclear factor kappa B helps predict Helicobacter pyloriindependent status of low-grade gastric mucosa-associated lymphoid tissue lymphomas with or without $\mathrm{t}(11 ; 18)(\mathrm{q} 21 ; \mathrm{q} 21)$. Blood 106: 1037-1041, 2005.

6 Isaacson P: Extranodal marginal zone lymphoma: MALT lymphoma. In: Hematopathology [Jaffe ES, Harris NL, Vardiman JW, Campo E and Arber DA (eds.)]. Elsevier, Philadelphia, pp. 291-305, 2010.

7 Hummel M, Oeschger S, Barth TFE, Loddenkemper C, Cogliatti SB, Marx A, Wacker HH, Feller AC, Bernd HW, Hansmann ML, Stein H and Möller P: Wotherspoon criteria combined with B cell clonality analysis by advanced polymerase chain reaction technology discriminates covert gastric marginal zone lymphoma from chronic gastritis. Gut 55: 782-787, 2006.

8 Bartel DP: MicroRNAs: target recognition and regulatory functions. Cell 136: 215-233, 2009.

9 O'Connell RM and Baltimore D: MicroRNAs and hematopoietic cell development. Curr Top Dev Biol 99: 145-174, 2012.

10 Di Lisio L, Martinez N, Montes-Moreno S, Piris-Villaespesa M, Sanchez-Beato M and Piris MA: The role of miRNAs in the pathogenesis and diagnosis of B-cell lymphomas. Blood 120 : 1782-1790, 2012.

11 Lawrie $\mathrm{CH}$ : MicroRNAs and lymphomagenesis: a functional review. Br J Haematol 160: 571-581, 2013.

12 Nardini E, Rizzi S, Ménard S and Balsari A: Molecular phenotype distinguishes two subsets of gastric low-grade mucosa-associated lymphoid tissue lymphomas. Lab Invest 82: 535-541, 2002. 
13 Huynh MQ, Wacker H-H, Wündisch T, Sohlbach K, Kim TD, Krause M, Stabla K, Roth P, Fischbach W, Stolte M and Neubauer A: Expression profiling reveals specific gene expression signatures in gastric MALT lymphomas. Leuk Lymphoma 49: 974-983, 2008.

14 Roehle A, Hoefig KP, Repsilber D, Thorns C, Ziepert M, Wesche KO, Thiere M, Loeffler M, Klapper W, Pfreundschuh M, Matolcsy A, Bernd HW, Reiniger L, Merz H and Feller AC: MicroRNA signatures characterize diffuse large B-cell lymphomas and follicular lymphomas. Br J Haematol 142: 732-744, 2008.

15 Malumbres R, Sarosiek KA, Cubedo E, Ruiz JW, Jiang X, Gascoyne RD, Tibshirani R and Lossos IS: Differentiation stagespecific expression of microRNAs in B lymphocytes and diffuse large B-cell lymphomas. Blood 113: 3754-3764, 2009.

16 Navarro A, Beà S, Fernández V, Prieto $M$, Salaverria I, Jares $P$, Hartmann E, Mozos A, López-Guillermo A, Villamor N, Colomer D, Puig X, Ott G, Solé F, Serrano S, Rosenwald A, Campo E and Hernández L: MicroRNA expression, chromosomal alterations, and immunoglobulin variable heavy chain hypermutations in Mantle cell lymphomas. Cancer Res 69: 7071-7078, 2009.

17 Zhang J, Jima DD, Jacobs C, Fischer R, Gottwein E, Huang G, Lugar, Patricia L, Lagoo AS, Rizzieri DA, Friedman DR, Weinberg JB, Lipsky PE and Dave SS: Patterns of microRNA expression characterize stages of human B-cell differentiation. Blood 113: 4586-4594, 2009.

18 Liu TY, Chen SU, Kuo SH, Cheng AL and Lin CW: E2A-positive gastric MALT lymphoma has weaker plasmacytoid infiltrates and stronger expression of the memory B-cell-associated miR-223: possible correlation with stage and treatment response. Mod Pathol 23: 1507-1517, 2010.

19 He M, Gao L, Zhang S, Tao L, Wang J, Yang J and Zhu M: Prognostic significance of miR-34a and its target proteins of FOXP1, p53, and BCL2 in gastric MALT lymphoma and DLBCL. Gastric Cancer 17: 431-441, 2014.

20 Swerdlow SH, Campo E, Harris NL, Jaffe ES, Pileri SA, Stein H, Thiele $\mathrm{J}$ and Vardiman JW: WHO Classification of Tumours of Haematopoietic and Lymphoid Tissue (IARC WHO Classification of Tumours) 4th Edition. Lyon, IARC Press, 2008.

21 Copie-Bergman C, Gaulard P, Lavergne-Slove A, Brousse N, Fléjou JF, Dordonne K, de Mascarel A and Wotherspoon AC: Proposal for a new histological grading system for post-treatment evaluation of gastric MALT lymphoma. Gut 52: 1656, 2003.

22 Salar A, Bellosillo B, Serrano S and Besses C: Persistent residual disease in $\mathrm{t}(11 ; 18)(\mathrm{q} 21 ; \mathrm{q} 21)$ positive gastric mucosa-associated lymphoid tissue lymphoma treated with chemotherapy or rituximab. J Clin Oncol 23: 7361-7362, 2005.

23 García M, Bellosillo B, Sánchez-González B, García-Payarols F, Seoane A, Ferrer AM, Gimeno E, Barranco LE, Torner A, Solé F, Besses C, Serrano S and Salar A: Study of regulatory T-cells in patients with gastric MALT lymphoma: influence on treatment response and outcome. PLoS One 7: e51681, 2012.

24 Van Dongen JJM, Langerak AW, Brüggemann M, Evans PAS, Hummel M, Lavender FL, Delabesse E, Davi F, Schuuring E, García-Sanz R, van Krieken JH, Droese J, González D, Bastard C, White HE, Spaargaren M, González M, Parreira A, Smith JL, Morgan GJ, Kneba $M$ and Macintyre EA: Design and standardization of PCR primers and protocols for detection of clonal immunoglobulin and T-cell receptor gene recombinations in suspect lymphoproliferations: report of the BIOMED-2 Concerted Action BMH4-CT98-3936. Leukemia 17: 2257-2317, 2003.
25 Navarro A, Pairet S, Álvarez-Larrán A, Pons A, Ferrer G, Longarón R, Fernández-Rodríguez C, Camacho L, Monzó M, Besses C and Bellosillo B: miR-203 and miR-221 regulate SOCS1 and SOCS3 in essential thrombocythemia. Blood Cancer J 6: e406, 2016.

26 Thorns C, Kuba J, Bernard V, Senft A, Szymczak S, Feller AC and Bernd HW: Deregulation of a distinct set of microRNAs is associated with transformation of gastritis into MALT lymphoma. Virchows Arch 460: 371-377, 2012.

27 Matsushima K, Isomoto $\mathrm{H}$, Inoue N, Nakayama T, Hayashi T, Nakayama M, Nakao K, Hirayama T and Kohno S: MicroRNA signatures in Helicobacter pylori-infected gastric mucosa. Int J Cancer 128: 361-370, 2011.

28 Xiao B, Liu Z, Li B-S, Tang B, Li W, Guo G, Shi Y, Wang F, Wu $\mathrm{Y}$, Tong WD, Guo H, Mao XH and Zou QM: Induction of microRNA-155 during Helicobacter pylori infection and its negative regulatory role in the inflammatory response. J Infect Dis 200: 916-925, 2009.

29 Fassi Fehri L, Koch M, Belogolova E, Khalil H, Bolz C, Kalali B, Bolz C, Kalali B, Mollenkopf HJ, Beigier-Bompadre M, Karlas A, Schneider T, Churin Y, Gerhard M and Meyer TF: Helicobacter pylori induces miR-155 in T cells in a cAMP-Foxp3-dependent manner. PLoS One 5: e9500, 2010.

30 Saito Y, Suzuki H, Tsugawa H, Imaeda H, Matsuzaki J, Hirata K, Hosoe N, Nakamura M, Mukai M, Saito $H$ and Hibi $T$ : Overexpression of miR-142-5p and miR-155 in Gastric MucosaAssociated Lymphoid Tissue (MALT) Lymphoma Resistant to Helicobacter pylori Eradication. PLoS One 7: 1-8, 2012.

31 Gebauer N, Kuba J, Senft A, Schillert A, Bernard V and Thorns C: MicroRNA-150 is up-regulated in extranodal marginal zone lymphoma of MALT type. Cancer Genomics and Proteomics 11: 51-56, 2014.

32 Musilova K and Mraz M: MicroRNAs in B-cell lymphomas: how a complex biology gets more complex. Leukemia 29: 1004-1017, 2015.

33 Eis PS, Tam W, Sun L, Chadburn A, Li Z, Gomez MF, Lund E and Dahlberg JE: Accumulation of miR-155 and BIC RNA in human B cell lymphomas. Proc Natl Acad Sci USA 102: 3627-3632, 2005.

34 Fang C, Zhu D-X, Dong H-J, Zhou Z-J, Wang Y-H, Liu L, Fan L, Miao KR, Liu P, Xu W and Li JY: Serum microRNAs are promising novel biomarkers for diffuse large B cell lymphoma. Ann Hematol 91: 553-559, 2012.

35 Due H, Svendsen P, Bødker JS, Schmitz A, Bøgsted M, Johnsen HE, El-Galaly TC, Roug AS and Dybkær K: miR-155 as a Biomarker in B-Cell Malignancies. Biomed Res Int 2016: 1-14, 2016.

36 Wan J, Xia L, Xu W and Lu N: Expression and function of miR-155 in diseases of the gastrointestinal tract. Int J Mol Sci 17: 709, 2016.

37 Dahlhaus M, Roolf C, Ruck S, Lange S, Freund M and Junghanss $\mathrm{C}$ : Expression and prognostic significance of hsa-miR-142-3p in acute leukemias. Neoplasma 60: 432-438, 2013.

38 Ramkissoon SH, Mainwaring LA, Ogasawara Y, Keyvanfar K, McCoy JP, Sloand EM, Kajigaya S and Young NS: Hematopoieticspecific microRNA expression in human cells. Leuk Res 30: 643647, 2006.

39 Landgraf P, Rusu M, Sheridan R, Sewer A, Iovino N, Aravin A, Pfeffer S, Rice A, Kamphorst AO, Landthaler M, Lin C, Socci ND, Hermida L, Fulci V, Chiaretti S, Foà R, Schliwka J, Fuchs U, Novosel A, Müller RU, Schermer B, Bissels U, Inman J, Phan Q, Chien M, Weir DB, Choksi R, De Vita G, Frezzetti D, 
Trompeter HI, Hornung V, Teng G, Hartmann G, Palkovits M, Di Lauro R, Wernet P, Macino G, Rogler CE, Nagle JW, Ju J, Papavasiliou FN, Benzing T, Lichter P, Tam W, Brownstein MJ, Bosio A, Borkhardt A, Russo JJ, Sander C, Zavolan M and Tuschl T: A mammalian microRNA expression atlas based on small RNA library sequencing. Cell 129: 1401-1414, 2007.

40 Krützfeldt J, Rajewsky N, Braich R, Rajeev KG, Tuschl T, Manoharan $\mathrm{M}$ and Stoffel M: Silencing of microRNAs in vivo with “antagomirs". Nature 438: 685-689, 2005.

41 Zhang Y, Roccaro AM, Rombaoa C, Flores L, Obad S, Fernandes SM, Sacco A, Liu Y, Ngo H, Quang P, Azab AK, Azab F, Maiso P, Reagan M, Brown JR, Thai TH, Kauppinen S and Ghobrial IM: LNA-mediated anti-miR-155 silencing in low-grade B-cell lymphomas. Blood 120: 1678-1686, 2012.

42 Babar IA, Cheng CJ, Booth CJ, Liang X, Weidhaas JB, Saltzman WM and Slack FJ: Nanoparticle-based therapy in an in vivo microRNA-155 (miR-155)-dependent mouse model of lymphoma. Proc Natl Acad Sci USA 109: 1695-1704, 2012.
43 Craig VJ, Cogliatti SB, Rehrauer H, Wündisch T and Müller A: Epigenetic silencing of microRNA-203 dysregulates ABL1 expression and drives Helicobacter-associated gastric lymphomagenesis. Cancer Res 71: 3616-3624, 2011.

44 Liu H, Ruskon-Fourmestraux A, Lavergne-Slove A, Ye H, Molina T, Bouhnik Y, Hamoudi RA, Diss TC, Dogan A, Megraud F, Rambaud JC, Du MQ and Isaacson PG: Resistance of $t(11 ; 18)$ positive gastric mucosa-associated lymphoid tissue lymphoma to Helicobacter pylori eradication therapy. Lancet 357: 39-40, 2001.

45 Ancochea Á, Salar A, García-Pallarols F, Gimeno E, FernándezRodriguez C and Sánchez-González B: Prognostic impact of anthracyclines in the treatment of aggressive lymphoma in patients over 70 years. Med Clin (Barc) 144: 544-547, 2015.

Received November 15, 2016

Revised December 9, 2016

Accepted December 15, 2016 